\title{
Grain filling and fatty acid composition of safflower fertilized with integrated nitrogen fertilizer and biofertilizers
}

\author{
Raouf Seyed Sharifi( ${ }^{(1)}$, Ali Namvar ${ }^{(2)}$ and Reza Seyed Sharifi(1) \\ (1)University of Mohaghegh Ardabili, College of Agricultural Sciences, Daneshgah Street, 56199-11367, Ardabil, Iran. E-mail: \\ raouf_ssharifi@yahoo.com, reza_seyedsharifi@yahoo.com ${ }^{(2)}$ Young Researchers and Elite Club, Ardabil Branch, Islamic Azad University, \\ Ardabil, Iran. E-mail: namvar_a60@yahoo.com
}

\begin{abstract}
The objective of this work was to evaluate the effects of the integrated application of nitrogen fertilizer and biofertilizers on the yield, grain filling period, and composition of fatty acids of safflower (Carthamus tinctorius). Split-plot experiments were carried out during the 2011 and 2012 crop seasons. The treatments consisted of seed inoculation with plant growth-promoting rhizobacteria (Azotobacter chroococcum strain 5, Azospirillum lipoferum strain F, and Pseudomonas putida strain 186) in the subplots, including a control without seed inoculation; and of the application of $\mathrm{N}$ fertilizer at different rates $(60,120$, and $180 \mathrm{~kg}$ $\mathrm{ha}^{-1}$ urea) in the main plots, including a control without N. The highest grain yield, grain filling period, and effective grain filling period were obtained by the application of $180 \mathrm{~kg} \mathrm{ha}^{-1}$ urea and by seed inoculation with $P$. putida. The application of high N rates and $P$. putida inoculation resulted in $25.66 \%$ increase of the potential rate of grain filling. Biofertilizer inoculation in seed reduced the contents of saturated fatty acids (palmetic and stearic acids) and increased the contents of unsaturated fatty acids (linoleic, linolenic, and oleic acids). The suitable amount of $\mathrm{N}$ fertilizer (between 120 and $180 \mathrm{~kg} \mathrm{ha}^{-1}$ urea) can improve plant growth, and the quantity and quality of oil in seeds treated with $P$. putida in safflower plants.

Index terms: Carthamus tinctorius, Pseudomonas putida, oil quality, PGPR, fatty acids, seed-inoculation.

\section{Enchimento de grãos e composição de ácidos graxos em plantas de cártamo adubadas com fertilizante nitrogenado e biofertilizantes}

\begin{abstract}
Resumo - O objetivo deste trabalho foi avaliar os efeitos da aplicação integrada de fertilizante nitrogenado e biofertilizantes sobre o rendimento, o período de enchimento de grãos e a composição de ácidos graxos de cártamo (Carthamus tinctorius). Os experimentos foram conduzidos em parcelas subdividas, durante as safras 2011 e 2012. Os tratamentos consistiram da inoculação de rizobactérias promotoras do crescimento de plantas (Azotobacter chroococcum estirpe 5, Azospirillum lipoferum estirpe F e Pseudomonas putida estirpe 186) nas sementes, nas subparcelas, com um controle sem inoculação; e da aplicação de diferentes níveis de adubação nitrogenada $\left(60,120\right.$ e $180 \mathrm{~kg} \mathrm{ha}^{-1}$ de ureia) nas parcelas principais, com um controle sem aplicação de N. O maior rendimento de grãos, o maior período de enchimento de grãos e o período efetivo de enchimento de grãos foram obtidos com a aplicação de $180 \mathrm{~kg} \mathrm{ha}^{-1}$ de ureia e com a inoculação de $P$. putida nas sementes. A aplicação de altas doses de $\mathrm{N}$ e a inoculação com $P$. putida resultaram no aumento de $25,66 \%$ da taxa potencial de enchimento de grãos. A inoculação de biofertilizantes nas sementes reduziu o teor de ácidos graxos saturados (ácidos palmítico e esteárico) e incrementou os ácidos graxos insaturados (ácidos linoleico, linolênico e oleico). A aplicação da quantidade adequada de adubação nitrogenada (120 a $180 \mathrm{~kg} \mathrm{ha}^{-1}$ de ureia) pode melhorar o crescimento de plantas e a quantidade e a qualidade do óleo das sementes tratadas com $P$. putida, em plantas de cártamo.
\end{abstract}

Termos para indexação: Carthamus tinctorius, Pseudomonas putida, qualidade do óleo, PGPR, ácidos graxos, inoculação em sementes.

\section{Introduction}

Safflower (Carthamus tinctorius L.) is one of the most important oil seed all over the world. It has a high need of nitrogen $(\mathrm{N})$ due to this nutrient multidimensional effects on the growth and development of this crop than other nutritional elements (Kulekci et al., 2009). Golzarfar et al. (2012) suggested that nutrient management is one of the critical inputs to achieve a high productivity of safflower. Hence, there is a need to improve this major component of the production technology to get a higher safflower production. 
Safflower N requirements depends on the amount of $\mathrm{N}$ in the soil, soil productivity, and preceding crop (Siddiqui \& Oad 2006). Soleymanifard \& Sidat (2011) suggested that yield and yield attribute of safflower increased by the increment of $\mathrm{N}$ application rate. This element is also the major macronutrient that determines the rate and period of grain filling. Final grain weight was related to grain filling rate, grain filling duration, and their interactions (Sadras \& Egli, 2008). Borrás et al. (2004) found that lack of assimilate supply, during the grain filling period, could result in a dramatic decline of grain weight. Dordas \& Sioulas (2008) reported that higher rates of $\mathrm{N}$ application increase the photosynthetic processes, leaf area production, and leaf area duration, as well as the grain filling period.

Although $\mathrm{N}$ is the key element for the increasing of safflower productivity, and, consequently for this crop production increment per unit of area, large rates of $\mathrm{N}$ fertilizer loss to the environment could cause a serious environmental problem, such as groundwater contamination. In such a situation, the reduction of $\mathrm{N}$ application rates to an optimized level, with the application of biofertilizers, can reduce the need for chemical fertilizers, decrease adverse environmental effects, increase soil organic matter, improve soil properties, and enhance crop yield. Therefore, in the development and implementation of sustainable agriculture techniques, biofertilization is important to alleviate environmental pollution and deterioration of nature (Namvar \& Khandan, 2015).

Safflower oil quality is determined by oil composition of saturated and unsaturated fatty acids. Nasim et al. (2012) concluded that $\mathrm{N}$ is the most important element to increase grain oil content. They stated that increasing $\mathrm{N}$ rates reduced seed oil percentages, but increased seed yield, and, consequently, increased oil yield per unit area. Silva et al. (2013) reported that biofertilizer inoculation in soybean enhanced oil content and unsaturated fatty acids, while decreased saturated fatty acids. Moreover, Mirzakhani et al. (2009) showed that safflower yield increased in plants inoculated with Azotobacter.

The determination of safflower response to $\mathrm{N}$ application and seed inoculation by biofertilizers is very important to maximize yield and economic profitability of safflower production. In addition, it seems that there is little investigation about the combined effects of $\mathrm{N}$ fertilization and biofertilizer on yield, grain filling period, and composition of fatty acids of safflower.

The objective of this work was to evaluate the effects of the integrated application of nitrogen fertilizer and biofertilizers on the yield, grain filling period, and composition of fatty acids of safflower (Carthamus tinctorius).

\section{Materials and Methods}

Field experiments were conducted in a randomized complete block design, in split plots with three replicates, during 2011 and 2012 crop seasons. The treatments were $\mathrm{N}$ applications at four rates (no $\mathrm{N}$ application as control, and 60,120, and $180 \mathrm{~kg} \mathrm{ha}^{-1}$ urea), assigned to the main plots; and seed treated by biofertilizer inoculations, assigned to the subplots, which were: no inoculation as control, and inoculation with Azotobacter chroococcum strain 5, Azospirillum lipoferum strain $\mathrm{F}$, and Pseudomonas putida strain 186 . The area is located at $38^{\circ} 15^{\prime} \mathrm{N}$ and $48^{\circ} 15^{\prime} \mathrm{E}, 1,350 \mathrm{~m}$ altitute. Mean temperature and precipitation during safflower growing seasons of 2011 and 2012 is presented in Figure 1. The studied area soil is an Entisol with a silty loam texture. Other physicochemical properties of soil are shown in Table 1.

In each plot, there were 5 rows of $6 \mathrm{~m}$. Plots and blocks were separated by $1 \mathrm{~m}$ unplanted distances. Seed were manually sown in individual hills between rows, and intra-row spacing was $50 \times 5 \mathrm{~cm}$. Seed of 'Padideh' safflower were planted on $18^{\text {th }}$ May in 2011, and on $27^{\text {th }}$ May in 2012. For inoculation, seed were coated with gum arabic as an adhesive, and rolled into the suspension of bacteria until uniformly coated. Strain and cell densities of microorganisms used as plant growth-promoting rhizobacteria (PGPR), in this experiment, were $10^{7}$ colony forming units (CFU). Bacteria were isolated from safflower rhizospheres by the Research Institute of Soil and Water, Tehran, Iran. Two seed were sown per hill; and two weeks after the emergence, one plant per hill was thinned at the 4-5 leaf stage. The field was immediately irrigated (by surface irrigation) after planting. Irrigation, weeding, and all other agronomic practices, except for those under study, were kept normal and uniform for all treatments. 
In each experimental plot, two beside rows and a $0.5 \mathrm{~m}$ space from the beginning and the ending of the central planting lines were set as margins, and measurements were performed on the three rows in the middle lines. The number of grains per head, number of secondary branches, and the number of grains per plant were determined on 10 randomly selected plants in each plot. Seed oil and fatty acids were extracted according to the Method 988.05 (1990) protocol.

In each sampling, three plants of each plot were taken for the investigation of grain filling parameters. The first samples were taken on the $12^{\text {th }}$ day after flowering, in both years, and the other samples were taken at 4-day intervals for determining the grain weight accumulation. At each sampling, grains were manually removed from the heads and dried at $80^{\circ} \mathrm{C}$ for 48 hours. Grain dry weight and number were used to calculate the average grain weight for each sample. The total duration of grain filling was determined for each treatment combination by fitting a bilinear model (Borrás \& Otegui, 2001):

$$
\mathrm{GW}=\left\{\begin{array}{l}
\mathrm{a}+\mathrm{gfr}(\mathrm{daa}), \ldots \ldots . . \mathrm{if} \ldots<\mathrm{p}_{\mathrm{m}} \\
\mathrm{a}+\operatorname{gfr}\left(\mathrm{p}_{\mathrm{m}}\right), \ldots . . . \text { if } \ldots . . \mathrm{daa} \geq \mathrm{p}_{\mathrm{m}}
\end{array}\right.
$$

in which: GW is the kernel dry weight; a is the GW intercept; gfr is the slope of grain weight, indicating grain filling rate; daa represents the days after flowering; and $\mathrm{p}_{\mathrm{m}}$ is the physiological maturity. Borrás et al. (2004) illustrated grain filling using a bilinear model. Effective grain filling duration (EGFD) was calculated according to Borrás \& Otegui (2001), as $\mathrm{EGFD}=$ the highest grain weight $(\mathrm{g}) /$ ratio of seed filling (g per day).

The kernel weight increase in the filling period was calculated by the above mentioned equation, using the Proc NLIN DUD of the statistical software SAS. Data were statistically analyzed by using SAS, version 9.1 (SAS Institute Inc., Cary, NC, USA). The analysis of variance was used to test the significance;
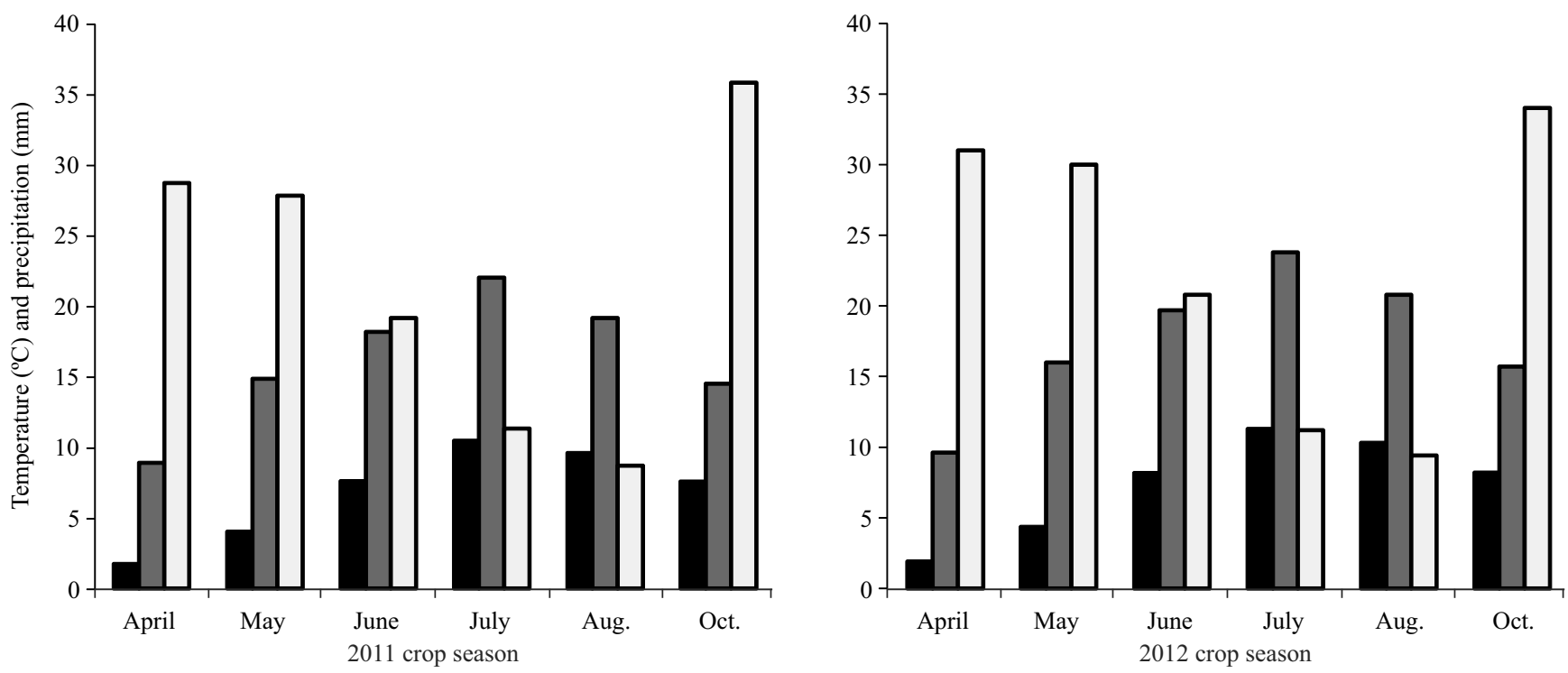

Mean low temprature $\square$ Mean high temprature $\quad$ Mean percipitation

Figure 1. Minimum and maximum temperatures, and precipitation recorded during 2011 and 2012 crop seasons, in Ardabil, Iran.

Table 1. Soil physicochemical properties of the entisol samples at $0-40-\mathrm{cm}$ depth in Ardabil, Iran.

\begin{tabular}{|c|c|c|c|c|c|c|c|c|c|c|}
\hline Year & Texture & $\begin{array}{c}\text { Sand } \\
\left(\mathrm{g} \mathrm{kg}^{-1}\right)\end{array}$ & $\begin{array}{c}\text { Silt } \\
\left(\mathrm{g} \mathrm{kg}^{-1}\right)\end{array}$ & $\begin{array}{c}\text { Clay } \\
\left(\mathrm{g} \mathrm{kg}^{-1}\right)\end{array}$ & $\begin{array}{c}\mathrm{CaCO}_{3} \\
(\%)\end{array}$ & $\begin{array}{c}\text { Organic carbon } \\
(\%)\end{array}$ & $\begin{array}{c}\text { Total N } \\
(\%)\end{array}$ & $\begin{array}{c}\text { Exchangeable } \mathrm{K} \\
\left(\mathrm{mg} \mathrm{kg}^{-1}\right)\end{array}$ & $\begin{array}{c}\text { Extractable P } \\
\left(\mathrm{mg} \mathrm{kg}^{-1}\right)\end{array}$ & $\mathrm{pH}$ \\
\hline 2011 & Silty loam & 240 & 700 & 50 & 18.3 & 0.78 & 0.16 & 385 & 16 & 8.2 \\
\hline 2012 & Silty loam & 265 & 680 & 47 & 18.0 & 0.74 & 0.15 & 378 & 16 & 8.1 \\
\hline
\end{tabular}


and LSD, at 5\% probability, was used to compare the means.

\section{Results and Discussion}

The number of secondary branches per plant increased about $31.6,23.0$, and $12.2 \%$ by the application of $180 \mathrm{~kg} \mathrm{ha}^{-1}$ urea, in comparison to the application of 0, 60, $120 \mathrm{~kg} \mathrm{ha}^{-1}$ urea, respectively (Table 2). Further, the lowest and the highest values of this trait were recorded for the treatments with 0 and $180 \mathrm{~kg} \mathrm{ha}^{-1}$ urea, respectively. Elfadl et al. (2009) and Golzarfar et al. (2012) reported similar results. Moreover, the greatest number of secondary branches per plant were observed in the inoculation treaments. Pseudomonas inoculation increased the number of secondary branches by $18.9 \%$ in comparison to the noninoculated treatments. These results are in agreement with those reported by Soleymanifard \& Sidat (2011) and Mirzakhani et al. (2009) in safflower. The comparison of means showed that the highest number of secondary branches was obtained in the application of $180 \mathrm{~kg} \mathrm{ha}^{-1}$ urea and seed inoculation with Pseudomonas, and the minimum value for this trait was obtained in no inoculation and no $\mathrm{N}$ application treatments (Table 3).
The highest number of grains per plant occurred with the $180 \mathrm{~kg} \mathrm{ha}^{-1}$ urea application, which increased this trait in $36.2 \%$ compared to the control in each plant (Table 2). Soleymanifard \& Sidat (2011) investigated the effects of $\mathrm{N}$ on the growth and yield of safflower, and reported that the number of grains per plant increased as a consequence of $\mathrm{N}$ doses up to $30 \mathrm{~kg} \mathrm{ha}^{-1}$, but further increase of $\mathrm{N}$ doses (30 to $60 \mathrm{~kg} \mathrm{ha}^{-1} \mathrm{~N}$ ) showed no significant effect on this trait. Biofertilizer inoculations increased the number of grains per plant. Plants treated with inoculation of Pseudomonas, Azospirillum, and Azotobacter showed 9.8, 9.1 and $8.4 \%$ more grains per plant than nontreated plants, respectively. Different rates of $\mathrm{N}$ fertilizer and inoculation had effects on the number of grains per head. The maximum number of grains per head was observed in the treatment of $180 \mathrm{~kg} \mathrm{ha}^{-1}$ urea, while the lowest values of this trait was obtained from the control (Table 2). The use of 180, 120, and $60 \mathrm{~kg} \mathrm{ha}^{-1}$ urea increased the number of grains per head by 27.7, 20.6 and $14.0 \%$, respectively. Dordas \& Sioulas (2008) reported that $\mathrm{N}$ fertilization increased the number of grains per head by $16 \%$ on average. Increasing the number of grains per head may be attributed to the delay of the vegetative and reproductive period, and to the lengthening of grain filling.

Table 2. Effects of biofertilizer (B) and nitrogen $(\mathrm{N})$ rates on grain filling and oil content of safflower (mean of two years, or combined analysis of the two years, 2011-2012) in the studied area, in Ardabil, Iran ${ }^{(1)}$.

\begin{tabular}{|c|c|c|c|c|c|c|c|c|c|c|c|c|c|}
\hline Treatment & NSB & $\mathrm{NGH}$ & $\begin{array}{c}\text { Grains } \\
\text { per plant }\end{array}$ & $\begin{array}{c}\text { EGFP } \\
\text { (day) }\end{array}$ & $\begin{array}{l}\text { GFR (g } \\
\text { per day) }\end{array}$ & $\begin{array}{l}\text { GFP } \\
\text { (day) }\end{array}$ & $\begin{array}{c}\mathrm{GY} \\
\left(\mathrm{kg} \mathrm{ha}^{-1}\right)\end{array}$ & $\begin{array}{l}\mathrm{OC} \\
(\%) \\
\end{array}$ & $\begin{array}{l}\text { PA } \\
(\%)\end{array}$ & $\begin{array}{l}\text { SA } \\
(\%) \\
\end{array}$ & $\begin{array}{l}\text { OA } \\
(\%)\end{array}$ & $\begin{array}{l}\text { Lila } \\
(\%)\end{array}$ & $\begin{array}{c}\begin{array}{c}\text { Linla } \\
(\%)\end{array} \\
\end{array}$ \\
\hline \multicolumn{14}{|l|}{ Nitrogen } \\
\hline $\mathrm{N}_{0}=0$ & $6.32 \mathrm{~d}$ & $25.28 \mathrm{~d}$ & $137.52 d$ & $24.48 \mathrm{c}$ & $0.00139 \mathrm{c}$ & $28.43 b$ & $1610.5 \mathrm{c}$ & $25.2 \mathrm{c}$ & $7.78 \mathrm{a}$ & $2.48 \mathrm{~b}$ & $13.41 \mathrm{c}$ & $60.75 d$ & $0.056 \mathrm{~d}$ \\
\hline $\mathrm{N}_{1}=60$ & $7.11 \mathrm{c}$ & $29.66 \mathrm{c}$ & $181.56 \mathrm{c}$ & $25.50 \mathrm{c}$ & $0.00148 \mathrm{~b}$ & $29.45 b$ & $1966.0 \mathrm{~b}$ & $26.3 b$ & $7.16 \mathrm{~b}$ & $2.44 \mathrm{c}$ & $13.64 \mathrm{c}$ & $61.56 \mathrm{c}$ & $0.061 \mathrm{c}$ \\
\hline $\mathrm{N}_{2}=120$ & $8.11 \mathrm{~b}$ & $31.86 \mathrm{~b}$ & $200.76 \mathrm{~b}$ & $28.84 \mathrm{~b}$ & $0.00162 \mathrm{a}$ & $34.49 a$ & $2160.1 \mathrm{a}$ & $27.6 \mathrm{a}$ & $6.95 b$ & $2.56 \mathrm{a}$ & $14.18 b$ & $63.45 \mathrm{~b}$ & $0.0707 \mathrm{a}$ \\
\hline $\mathrm{N}_{3}=180$ & $9.24 \mathrm{a}$ & $34.98 \mathrm{a}$ & $215.76 \mathrm{a}$ & $30.49 \mathrm{a}$ & $0.00160 \mathrm{a}$ & $35.23 \mathrm{a}$ & $2262.2 \mathrm{a}$ & $25.5 \mathrm{c}$ & $6.42 \mathrm{c}$ & $2.57 \mathrm{a}$ & $15.30 \mathrm{a}$ & $64.37 \mathrm{a}$ & $0.066 \mathrm{~b}$ \\
\hline LSD 5\% & 0.504 & 1.62 & 13.56 & 1.12 & 0.000431 & 1.38 & 114.7 & 0.428 & 0.224 & 0.022 & 0.336 & 0.665 & 0.0025 \\
\hline \multicolumn{14}{|c|}{ Biofertilizer } \\
\hline $\mathrm{B}_{0}$ & $7.18 \mathrm{~b}$ & $28.27 d$ & $171.00 \mathrm{~b}$ & $25.75 \mathrm{~d}$ & $0.00149 \mathrm{~b}$ & $30.12 d$ & $1930.2 \mathrm{c}$ & $24.9 \mathrm{c}$ & $8.25 \mathrm{a}$ & $2.70 \mathrm{a}$ & $12.90 \mathrm{~d}$ & $60.16 \mathrm{~d}$ & $0.052 \mathrm{~d}$ \\
\hline $\mathrm{B}_{1}$ & $8.86 a$ & $31.92 \mathrm{a}$ & $189.62 \mathrm{a}$ & $28.97 \mathrm{a}$ & $0.00170 \mathrm{a}$ & $33.64 \mathrm{a}$ & $2075.8 \mathrm{a}$ & $26.4 \mathrm{a}$ & $6.25 \mathrm{~d}$ & $2.51 \mathrm{~b}$ & $14.47 \mathrm{a}$ & $64.37 \mathrm{a}$ & $0.069 \mathrm{a}$ \\
\hline $\mathrm{B}_{2}$ & $7.39 b$ & $30.30 \mathrm{c}$ & $188.28 \mathrm{a}$ & $27.96 \mathrm{~b}$ & $0.00149 \mathrm{~b}$ & $31.24 \mathrm{c}$ & $1979.4 \mathrm{~b}$ & $25.9 \mathrm{~b}$ & $6.64 c$ & $2.68 \mathrm{a}$ & $13.95 \mathrm{~b}$ & $62.29 \mathrm{~b}$ & $0.650 \mathrm{~b}$ \\
\hline $\mathrm{B}_{3}$ & $7.35 \mathrm{~b}$ & $31.27 \mathrm{~b}$ & $186.72 \mathrm{a}$ & $26.69 \mathrm{c}$ & $0.00151 \mathrm{~b}$ & $32.60 \mathrm{~b}$ & $1989.5 \mathrm{~b}$ & $25.9 \mathrm{~b}$ & $7.11 \mathrm{~b}$ & $2.68 \mathrm{a}$ & $13.64 \mathrm{c}$ & $61.23 \mathrm{c}$ & $0.058 \mathrm{c}$ \\
\hline LSD 5\% & 0.313 & 0.636 & 3.47 & 0.56 & 0.0004 & 0.61 & 91.3 & 0.251 & 0.345 & 0.036 & 0.263 & 0.717 & 0.0025 \\
\hline $\mathrm{N}$ & $*$ & $*$ & $*$ & $* *$ & $* *$ & $* *$ & $*$ & $*$ & $*$ & $*$ & $* *$ & $*$ & $*$ \\
\hline B & $*$ & $* *$ & $* *$ & $* *$ & $* *$ & $* *$ & $* *$ & $*$ & $* *$ & $*$ & $*$ & $*$ & $* *$ \\
\hline $\mathrm{N} \times \mathrm{B}$ & $*$ & $*$ & $* *$ & $* *$ & $* *$ & $* *$ & $*$ & $* *$ & $*$ & ns & ns & $* *$ & ns \\
\hline
\end{tabular}

${ }^{n}$ Nonsignificant. *, **Significant differences at $5 \%$ and $1 \%$ probability, respectively. NSB, number of secondary branches; NGH, number of grains per head; EGFP, effective grain filling period; GFR, grain filling rate; GFP, grain filling period; GY, grain yield; OC, oil content; PA, palmitic acid; SA, stearic acid; OA, oleic acid; Lila, linoleic acid; Linla, linolenic acid. $\mathrm{N}_{0}$, no nitrogen application; $\mathrm{N}_{1}, \mathrm{~N}_{2}$, and $\mathrm{N}_{3}$, application of 60,120 , and $180 \mathrm{~kg}$ ha ${ }^{-1}$ urea, respectively. $\mathrm{B}_{0}$, no seed inoculation; $\mathrm{B}_{1}, \mathrm{~B}_{2}$, and $\mathrm{B}_{3}$, seed inoculation by Pseudomonas putida strain 186, Azospirillum lipoferum strain $\mathrm{F}$, and Azotobacter chroococcum strain 5, respectively. 
Application of high $\mathrm{N}$ rates (180 kg ha-1 urea) and seed inoculation by Pseudomonas resulted in $25.66 \%$ increase of the grain filling potential rate, in comparison to the control (Table 2). In other words, peak grain filling rates lasted longer in the treatment with high $\mathrm{N}$ rates and seed inoculation with Pseudomonas than the control treatment (Figure 2 D). Borrás et al. (2004) reported that the lack of assimilate supply, could result in a dramatic decline in grain filling period and grain weight. Massignam et al. (2009) noted that N plays an imperative role in the maximization of crop yields, via its effects on photosynthetic processes such as grain filling rate and grain filling period. Abbadi et al. (2008) showed that increasing $\mathrm{N}$ fertilizer rates increased traits related to grain growth in safflower. Moreover, Hamidi et al. (2009) stated that grain filling period was prolonged due to inoculation by PGPR in maize hybrids. They suggested that inoculation by PGPR by various mechanisms - such as the ability to produce indoleacetic acid, gibberelic acid, cytokines, symbiotic $\mathrm{N}$ fixation, and antagonism to phytopathogenic microorganisms by the production of siderophores causes the increase of grain filling period. High grain filling rate by the application of $180 \mathrm{~kg} \mathrm{ha}^{-1}$ urea and seed inoculation by Pseudomonas could result from sufficient assimilate supply and large partitioning capacity.

Grain filling duration was delayed by seed inoculation, high rates of $\mathrm{N}$ application, and their combinations as compared to the control. The maximum grain filling duration was observed in the treatment with the highest $\mathrm{N}$ rate (Table 2). Among the biofertilizer treatments, seed inoculation by Pseudomonas increased grain filling duration more than Azotobacter and Azospirillum. Grain filling duration increased in plots that received the highest rate of $\mathrm{N}$ application and seed inoculation by Pseudomonas (Table 3). Similar results were obtained in effective grain filling period. Hamidi et al. (2009) reported that high $\mathrm{N}$ rates significantly delay the duration of the vegetative and reproductive periods, and could be the possible reason for lengthening of grain filling duration.

Effects of $\mathrm{N}$ rates on fatty acid compositions were significant (Table 2). Linoleic acid $\left(\mathrm{C}_{18: 2}\right)$ was the most abundant fatty acid, ranging between $60.75-64.37 \%$, followed by oleic acid $\left(\mathrm{C}_{18: 1}, 13.41-15.3 \%\right)$ and palmitic acid $\left(\mathrm{C}_{16: 0}, 6.95-7.78 \%\right)$, by the application of 0 and $180 \mathrm{~kg} \mathrm{ha}^{-1}$ urea respectively. The amount ranges of linolenic acid $\left(\mathrm{C}_{18: 3}\right)$ and stearic acid $\left(\mathrm{C}_{18: 1}\right)$ were

Table 3. Effects of biofertilizer (B) and $\mathrm{N}$ rates on grain filling and oil content of safflower (mean of two years, or combined analysis of the two years, 2011-2012) in the studied area, Ardabil, Iran ${ }^{(1)}$.

\begin{tabular}{|c|c|c|c|c|c|c|c|c|c|c|c|}
\hline $\begin{array}{l}\text { Treatment } \\
\text { compound }\end{array}$ & NSB & $\begin{array}{c}\text { Grains } \\
\text { per plant }\end{array}$ & $\begin{array}{c}\text { GFR } \\
\text { (g per day) }\end{array}$ & $\begin{array}{c}\text { EGFP } \\
\text { (day) }\end{array}$ & $\begin{array}{l}\text { GFP } \\
\text { (day) }\end{array}$ & $\begin{array}{c}\text { Fitted } \\
\text { equations }\end{array}$ & $\mathrm{NGH}$ & $\begin{array}{l}\mathrm{OC} \\
(\%)\end{array}$ & $\begin{array}{l}\text { PA } \\
(\%)\end{array}$ & $\begin{array}{c}\text { Linla } \\
(\%)\end{array}$ & $\begin{array}{c}\mathrm{GY} \\
\left(\mathrm{kg} \mathrm{ha}^{-1}\right)\end{array}$ \\
\hline $\mathrm{N}_{0} \mathrm{~B}_{0}$ & $5.56 \mathrm{~h}$ & $118.4 \mathrm{i}$ & $0.00139 \mathrm{f}$ & $23.03 j$ & $26.71 \mathrm{k}$ & $y=-0.00972+0.00146 x$ & $21.26 \mathrm{i}$ & $27.9 \mathrm{i}$ & $7.78 \mathrm{a}$ & $60.75 \mathrm{i}$ & $1515.3 \mathrm{i}$ \\
\hline $\mathrm{N}_{0} \mathrm{~B}_{1}$ & $7.32 \mathrm{ef}$ & $152.7 \mathrm{~g}$ & $0.00157 \mathrm{c}$ & $25.93 f$ & $29.98 \mathrm{gh}$ & $y=-0.013+0.0016 x$ & $28.38 \mathrm{~g}$ & $31.4 \mathrm{def}$ & $7.16 \mathrm{c}$ & $64.37 \mathrm{c}$ & $2238.3 b c$ \\
\hline $\mathrm{N}_{0} \mathrm{~B}_{2}$ & $6.14 \mathrm{~g}$ & $140.8 \mathrm{~h}$ & $0.00149 \mathrm{~d}$ & $24.81 \mathrm{~g}$ & 28.95hi & $y=-0.00997+0.00147 x$ & $25.48 \mathrm{~h}$ & $31.16 \mathrm{fg}$ & $6.42 \mathrm{f}$ & $63.45 \mathrm{de}$ & $2130.9 \mathrm{~d}$ \\
\hline $\mathrm{N}_{0} \mathrm{~B}_{3}$ & $6.28 \mathrm{~g}$ & $142.1 \mathrm{~h}$ & $0.00145 \mathrm{de}$ & $23.71 \mathrm{ji}$ & $27.7 \mathrm{kj}$ & $y=-0.00976+0.0015 x$ & $26.45 \mathrm{~h}$ & $30.92 \mathrm{~g}$ & $6.25 f$ & $61.56 \mathrm{~h}$ & $1943.8 \mathrm{f}$ \\
\hline $\mathrm{N}_{1} \mathrm{~B}_{0}$ & $6.52 \mathrm{~g}$ & $159.2 \mathrm{~g}$ & $0.00144 \mathrm{e}$ & 23.94hi & $27.0 \mathrm{k}$ & $y=-0.00647+0.0014 x$ & $28.02 \mathrm{~g}$ & $31.28 \mathrm{efg}$ & $7.57 \mathrm{~b}$ & $60.70 \mathrm{i}$ & $1605.2 \mathrm{~h}$ \\
\hline $\mathrm{N}_{1} \mathrm{~B}_{1}$ & $7.73 \mathrm{de}$ & $191.7 f$ & $0.00159 \mathrm{bc}$ & 26.31ef & $31.39 f$ & $y=-0.0107+0.00163 x$ & $30.29 f$ & $32.85 \mathrm{~cd}$ & $6.95 \mathrm{~d}$ & $65.14 b$ & $2249.6 \mathrm{bc}$ \\
\hline $\mathrm{N}_{1} \mathrm{~B}_{2}$ & $7.00 \mathrm{f}$ & $191.7 \mathrm{f}$ & $0.00149 \mathrm{~d}$ & 26.31ef & $30.19 \mathrm{~g}$ & $y=-0.00785+0.00146 x$ & $30.07 f$ & $31.77 \mathrm{~cd}$ & $6.32 \mathrm{f}$ & $63.62 \mathrm{de}$ & $2174.4 \mathrm{~cd}$ \\
\hline $\mathrm{N}_{1} \mathrm{~B}_{3}$ & $7.00 \mathrm{f}$ & $188.0 \mathrm{f}$ & $0.00145 \mathrm{de}$ & 24.71gh & $28.6 \mathrm{ji}$ & $y=-0.00967+0.0015 x$ & $30.68 \mathrm{ef}$ & $31.52 \mathrm{def}$ & $6.27 f$ & $62.24 \mathrm{~g}$ & $1959.3 \mathrm{ef}$ \\
\hline $\mathrm{N}_{2} \mathrm{~B}_{0}$ & $7.97 \mathrm{~d}$ & 195.3ef & $0.00139 f$ & 27.1de & $32.59 \mathrm{e}$ & $y=-0.0064+0.0014 x$ & $29.95 \mathrm{f}$ & $31.64 \mathrm{cde}$ & $5.80 \mathrm{~g}$ & $61.38 \mathrm{~h}$ & $1735.4 \mathrm{~g}$ \\
\hline $\mathrm{N}_{2} \mathrm{~B}_{1}$ & $9.18 b$ & $203.5 \mathrm{de}$ & $0.00159 \mathrm{bc}$ & $30.19 \mathrm{ab}$ & $35.68 \mathrm{~b}$ & $y=-0.0099+0.00168 x$ & $33.09 \mathrm{~cd}$ & $33.34 \mathrm{a}$ & $5.95 \mathrm{~g}$ & $66.61 \mathrm{a}$ & $2278.9 \mathrm{ab}$ \\
\hline $\mathrm{N}_{2} \mathrm{~B}_{2}$ & $7.73 \mathrm{de}$ & $206.6 \mathrm{~cd}$ & $0.00158 \mathrm{c}$ & $29.4 b$ & $34.88 \mathrm{bc}$ & $y=-0.00803+0.00148 x$ & $31.89 \mathrm{de}$ & $32.01 \mathrm{c}$ & $6.26 \mathrm{f}$ & $63.89 \mathrm{~cd}$ & $2190.1 \mathrm{~cd}$ \\
\hline $\mathrm{N}_{2} \mathrm{~B}_{3}$ & 7.61de & 203.1de & $0.00147 \mathrm{~cd}$ & $28.2 \mathrm{c}$ & $33.78 \mathrm{~cd}$ & $y=-0.0102+0.0016 x$ & $33.09 \mathrm{~cd}$ & $32.49 \mathrm{~b}$ & $6.72 \mathrm{e}$ & $62.62 \mathrm{fg}$ & $1988.8 \mathrm{ef}$ \\
\hline $\mathrm{N}_{3} \mathrm{~B}_{0}$ & $8.56 \mathrm{c}$ & $207.9 \mathrm{bcd}$ & $0.00158 \mathrm{c}$ & $27.9 \mathrm{~cd}$ & $33.58 \mathrm{de}$ & $y=-0.00881+0.00164 x$ & $34.3 \mathrm{bc}$ & $29.35 \mathrm{~h}$ & $6.95 \mathrm{~d}$ & $62.24 \mathrm{~g}$ & $1788.3 \mathrm{~g}$ \\
\hline $\mathrm{N}_{3} \mathrm{~B}_{1}$ & $11.35 \mathrm{a}$ & $219.0 \mathrm{a}$ & $0.00187 \mathrm{a}$ & $30.79 a$ & $36.87 \mathrm{a}$ & $y=-0.0121+0.00191 x$ & $36.6 \mathrm{a}$ & $31.64 \mathrm{cde}$ & $5.83 \mathrm{~g}$ & $65.36 \mathrm{~b}$ & $2344.0 \mathrm{a}$ \\
\hline $\mathrm{N}_{3} \mathrm{~B}_{2}$ & $8.69 \mathrm{c}$ & $217.6 \mathrm{ab}$ & $0.00163 b$ & $29.7 b$ & $35.48 b$ & $y=-0.0104+0.00165 x$ & $34.3 b c$ & $31.52 \mathrm{def}$ & $6.25 f$ & $64.44 \mathrm{c}$ & $2237.4 b c$ \\
\hline $\mathrm{N}_{3} \mathrm{~B}_{3}$ & $8.51 \mathrm{c}$ & $215.4 \mathrm{abc}$ & $0.00159 \mathrm{bc}$ & $28.5 \mathrm{c}$ & $34.28 \mathrm{~cd}$ & $y=-0.00971+0.00169 x$ & $35.51 \mathrm{ab}$ & $31.77 \mathrm{~cd}$ & $6.25 \mathrm{f}$ & $63.14 \mathrm{ef}$ & $2024.4 \mathrm{e}$ \\
\hline LSD & 0.438 & 9.92 & 0.000394 & 0.81 & 1.11 & - & 1.27 & 0.4031 & 0.196 & 0.572 & 79.45 \\
\hline
\end{tabular}

${ }^{(1)}$ Means with equal letters, in the columns, are not different by LSD test at $5 \%$ of probability. $\mathrm{N}_{0}$, no nitrogen application; $\mathrm{N}_{1}, \mathrm{~N}_{2}$, and $\mathrm{N}_{3}$, application of 60,120 , and $180 \mathrm{~kg} \mathrm{ha}^{-1}$ urea, respectively. $\mathrm{B}_{0}$, no seed inoculation; $\mathrm{B}_{1}, \mathrm{~B}_{2}$, and $\mathrm{B}_{3}$, seed inoculation by Pseudomonas putida strain 186 , Azospirillum lipoferum strain F, and Azotobacter chroococcum strain 5, respectively. NSB, number of secondary branches; GFR, grain filling rate; EGFP, effective grain filling period; GFP, grain filling period; NGH, number of grains per head; OC, oil content; PA, palmitic acid; Linla, linolenic acid; GY, grain yield. 
$0.056-0.0707 \%$ and $2.48-2.57 \%$, respectively; these ranges are similar to those reported by Coşge et al. (2007) in safflower. The application of $120 \mathrm{~kg} \mathrm{ha}^{-1}$ urea increased the linoleic acid content in 5.6, 4.36, and $1.4 \%$, in comparison to the applications of 0 , 60 , and $180 \mathrm{~kg} \mathrm{ha}^{-1}$ urea, respectively. Safflower oil composition determines the oil quality, and the oil fatty acid composition varies according to the environmental conditions during grain filling. Pseudomonas inoculation induced $6.5 \%$ increase of linoleic acid content (Table 2). The saturated fatty acids (palmitic and stearic acids) reduced in the treatment with Pseudomonas inoculation, in comparison to the control, while unsaturated fatty acids (linoleic, linolenic, and oleic acids) increased. Silva et al. (2013) reported that the biofertilizer inoculation enhances fatty acids content of soybean seed. The comparison of means showed that both inoculation and $\mathrm{N}$ application induced a content increase of linoleic acid. The treatments with application of 60,120 , and $180 \mathrm{~kg} \mathrm{ha}^{-1}$ urea and the Pseudomonas inoculation showed the highest linoleic fatty acid content -6.73 , 8.1 , and $7 \%$ increase, respectively, in comparison to the control. Conversely, these treatments resulted in the lowest content of palmitic acid, with 10.8, 23.0, and $25.5 \%$ decrease, respectively. Silva et al. (2013) reported that the biofertilizer inoculation enhances unsaturated fatty acids content of soybean seed. Similar results have been reported by Coşge et al. (2007) in safflower.
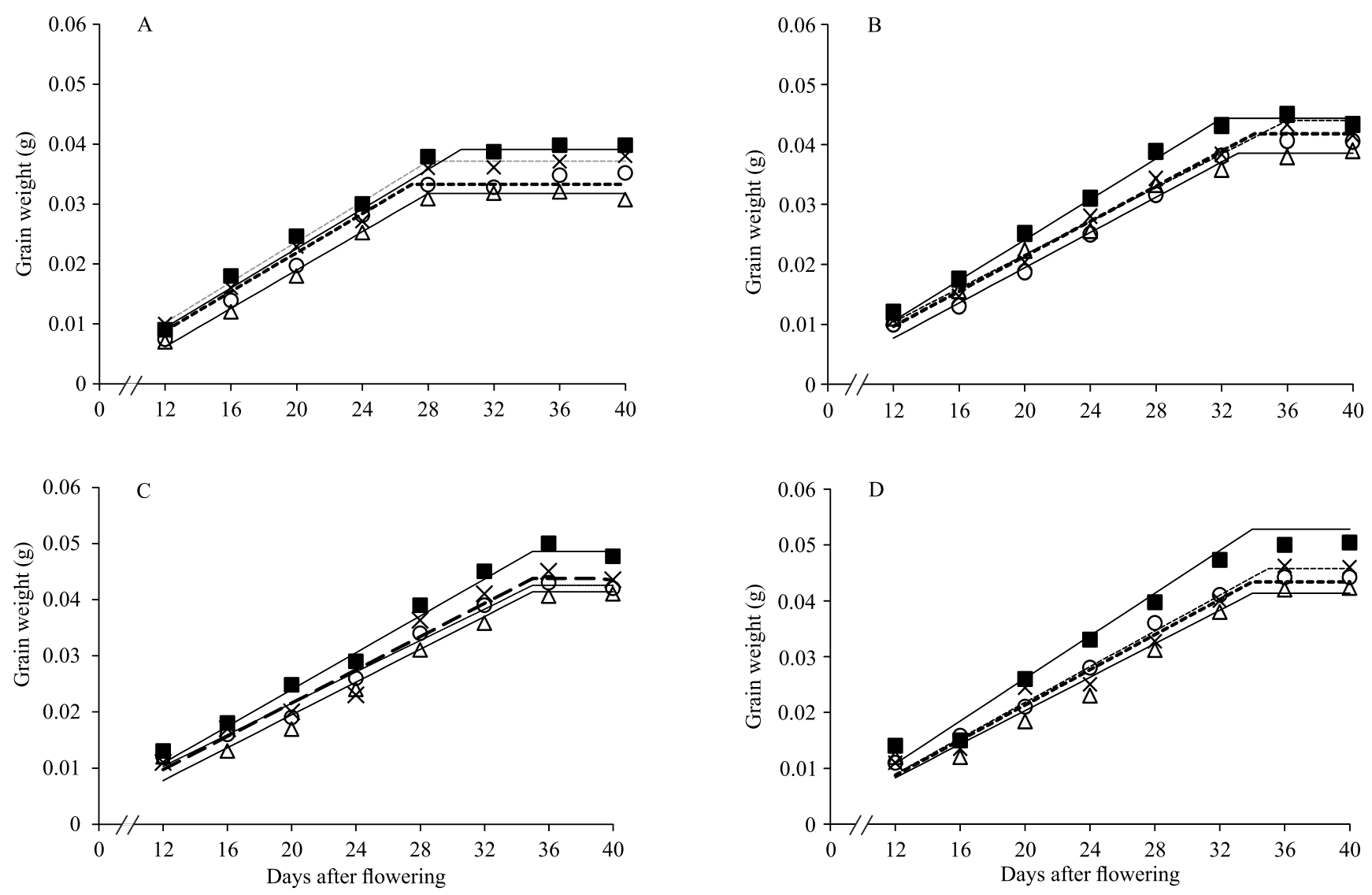

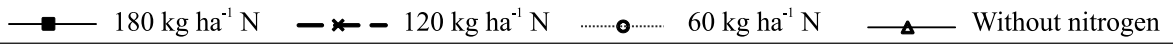

Figure 2. Variation of grain weight and of grain filling period in safflower plants subjected to $\mathrm{N}$ application at various rates, and seed inoculation by biofertilizers. A, no seed inoculation. Seed inoculation: B, by Azotobacter chroococcum strain 5; C, by Azospirillum lipoferum strain F; and D, by Pseudomonas putida strain 186. Mean of two years, or combined analysis of the two years (2011-2012) in the studied area, in Ardabil, Iran. 
Oil content is one of the more important components, which play a crucial role, in safflower seed quality. A slight increase of oil content was observed by increasing $\mathrm{N}$ rates up to $120 \mathrm{~kg} \mathrm{ha}^{-1}$ urea; however, by applying the highest $\mathrm{N}$ level, the oil content decreased again, which agrees with Abbadi et al. (2008), who found that at high $\mathrm{N}$ levels there was a significant decrease of oil content. However, Dordas \& Sioulas (2008) found no relationship between $\mathrm{N}$ rates and oil content. In the present study, the maximum seed oil content was obtained by applying $120 \mathrm{~kg} \mathrm{ha}^{-1}$ urea and Pseudomonas inoculation; minimum seed oil content was observed in the control treatment (Table 3). The seed oil content increased by $8.7 \%$ with increasing $\mathrm{N}$ applications from 0 to $120 \mathrm{~kg} \mathrm{ha}^{-1}$ urea, and, then, it decreased significantly. Golzarfar et al. (2012) found that increasing $\mathrm{N}$ rates from 0 to $150 \mathrm{~kg} \mathrm{ha}^{-1}$ urea increased the means of all traits, except for seed oil content which had a slight decrease in the highest level of N. Biofertilizer inoculated plants showed a higher seed oil content than the control plants (Table 2). Pseudomonas inoculation induced $5.6 \%$ increase of oil content, in comparison to the control treatment. Both inoculation and $\mathrm{N}$ application induced an increase of oil content. The treatments with $120 \mathrm{~kg} \mathrm{ha}^{-1}$ urea and seed inoculation by Pseudomonas showed the highest oil content (16.3\% increase). Shehata \& El-Khawas (2003) reported that seed treated with PGPR inoculation increased oil content of sunflower. Silva et al. (2013), in a soybean study, and Coşge et al. (2007), in a safflower study, reported similar results.

The different combinations of seed treated with biofertilizer inoculation and $\mathrm{N}$-fertilization treatments had effect on the grain yield of safflower (Table 3). The highest grain yield was obtained in the integrated treatment of $180 \mathrm{~kg} \mathrm{ha}^{-1}$ urea and Pseudomonas inoculation, which had a significant difference in comparison to other integrated treatments. The minimum grain yield was obtained in the control treatment. Biofertilizer applications showed a promoting effect on the grain yield, comparing with the uninoculated treatments. The biofertilizer treatment with Pseudomonas, Azotobacter, and Azospirillum increased grain yield by $6.97,2.5$, and $3.0 \%$, respectively, in comparison to the control. Similar findings were also reported by Shoghi-Kalkhoran et al. (2013), who stated that biofertilizer alone, or in combination with synthetic fertilizers, significantly increased grain. Stimulation of different crops by biofertilizer inoculations has also been shown by other studies, both in laboratory and field trials. According to Stefan et al. (2013), yield increased up to $18.42 \%$ with Bacillus pummilus inoculation, and up to $33.36 \%$ with Bacillus mycoides inoculants. Soleymanifard \& Siadat (2011) have been shown that safflower yield increased by the seed treatment with PGPR inoculation.

\section{Conclusions}

1. Biofertilizer inoculation and $\mathrm{N}$ application have effects on the grain filling period, and on the quantitative and qualitative yield of safflower.

2. Contents of saturated fatty acids reduce as a consequence of seed treated with biofertilizer inoculations, while unsaturated fatty acids increase.

3. The suitable amount of $\mathrm{N}$ fertilizer application (between 120 and $180 \mathrm{~kg} \mathrm{ha}^{-1}$ urea) can improve plant growth and the quantity and quality of oil, in seed treated with Pseudomonas putida inoculation, in safflower plants.

\section{References}

ABBADI, J.; GERENDÁS, J.; SATTELMACHER, B. Effects of nitrogen supply on growth, yield and yield components of safflower and sunflower. Plant and Soil, v.306, p.167-180, 2008. DOI: $10.1007 / \mathrm{s} 11104-008-9569-5$.

BORRÁS, L.; OTEGUI, M.E. Maize kernel weight response to postflowering source-sink ratio. Crop Science, v.41, p.1816-1822, 2001. DOI: $10.2135 /$ cropsci2001.1816.

BORRÁS, L.; SLAFER, G.A.; OTEGUI, M.E. Seed dry weight response to source-sink manipulations in wheat, maize and soybean: a quantitative reappraisal. Field Crops Research, v.86, p.131-146, 2004. DOI: 10.1016/j.fcr.2003.08.002.

COŞGE, B.; GÜRBÜZ, B.; KIRALAN, M. Oil content and fatty acid composition of some safflower (Carthamus tinctorius L.) varieties sown in spring and winter. International Journal of Natural and Engineering Sciences, v.1, p.11-15, 2007.

DORDAS, C.A.; SIOULAS, C. Safflower yield, chlorophyll content, photosynthesis, and water use efficiency response to nitrogen fertilization under rainfed conditions. Industrial Crops and Products, v.27, p.75-85, 2008. DOI: 10.1016/j. indcrop.2007.07.020.

ELFADL, E.; REINBRECHT, C.; FRICK, C.; CLAUPEIN, W. Optimization of nitrogen rate and seed density for safflower (Carthamus tinctorius L.) production under low-input farming 
conditions in temperate climate. Field Crops Research, v.114, p.2-13, 2009. DOI: 10.1016/j.fcr.2009.06.012.

GOLZARFAR, M.; SHIRANI RAD, A.H.; DELKHOSH, B.; BITARAFAN, Z. Safflower (Carthamus tinctorius L.) response to different nitrogen and phosphorus fertilizer rates in two planting seasons. Žemdirbystė-Agriculture, v.99, p.159-166, 2012.

HAMIDI, A.; CHAOKAN, R.; ASGHARZADEH, A.; DEHGHANSHOAR, M.; GHALAVAND, A.; MALAKOUTI, M.J. Effect of plant growth promoting rhizobacteria (PGPR) on phenology of late maturity maize (Zea mays L.) hybrids. Iranian Journal of Crop Sciences, v.11, p.249-270, 2009.

KULEKCI, M.; POLAT, T.; OZTURK, E. The determination of economically optimum nitrogen dose in safflower production under dry conditions. Bulgarian Journal of Agricultural Science, v.15, p.341-346, 2009.

MASSIGNAM, A.M.; CHAPMAN, S.C.; HAMMER, G.L.; FUKAI, S. Physiological determinants of maize and sunflower grain yield as affected by nitrogen supply. Field Crops Research, v.113, p.256-267, 2009. DOI: 10.1016/j.fcr.2009.06.001.

METHOD 988.05. In: HELRICH, K. (Ed.). Official methods of analysis of the AOAC. $15^{\text {th }}$ ed. Arlington: Association of Official Analytical Chemists, 1990.

MIRZAKHANI, M.; ARDAKANI, M.R.; AEENE BAND, A.; REJALI, F.; SHIRANI RAD, A.H. Response of spring safflower to co-inoculation with Azotobacter chroococum and Glomus intraradices under different levels of nitrogen and phosphourus. American Journal of Agricultural and Biological Sciences, v.4, p.255-261, 2009. DOI: 10.3844/ajabssp.2009.255.261.

NAMVAR, A.; KHANDAN, T. Inoculation of rapeseed under different rates of inorganic nitrogen and sulfur fertilizer: impact on water relations, cell membrane stability, chlorophyll content and yield. Archives of Agronomy and Soil Science, v.61, p.11371149, 2015. DOI: 10.1080/03650340.2014.982550.

NASIM, W.; AHMAD, A.; HAMMAD, H.M.; CHAUDHARY, H.J.; MUNIS, M.F.H. Effect of nitrogen on growth and yield of sunflower under semi-arid conditions of Pakistan. Pakistan Journal of Botany, v.44, p.639-648, 2012.

SADRAS, V.O.; EGLI, D.B. Seed size variation in grain crops: allometric relationships between rate and duration of seed growth. Crop Science, v.48, p.408-416, 2008. DOI: 10.2135/ cropsci2007.05.0292.

SHEHATA, M.M.; EL-KHAWAS, S.A. Effect of two biofertilizers on growth parameters, yield characters, nitrogenous components, nucleic acids content, minerals, oil content, protein profiles and DNA banding pattern of sunflower (Helianthus annus L. cv. Vedock) yield. Pakistan Journal of Biological Sciences, v.6, p.1257-1268, 2003. DOI: 10.3923/pjbs.2003.1257.1268.

SHOGHI-KALKHORAN, S.; GHALAVAND, A.; MODARRESSANAVY, S.A.M.; MOKHTASSI-BIDGOLI, A.; AKBARI, P. Integrated fertilization systems enhance quality and yield of sunflower (Helianthus annuus L.). Journal of Agricultural Science and Technology, v.15, p.1343-1352, 2013.

SIDDIQUI, M.H.; OAD, F.C. Nitrogen requirement of safflower (Carthamus tinctorius L.) for growth and yield traits. Asian Journal of Plant Sciences, v.5, p.563-565, 2006. DOI: 10.3923/ ajps.2006.563.565.

SILVA, L.R.; PEREIRA, M.J.; AZEVEDO, J.; MULAS, R.; VELASQUEZ, E.; GONZÁLEZ-ANDRÉS, F.; VALENTÃO, P.; ANDRADE, P.B. Inoculation with Bradyrhizobium japonicum enhances the organic and fatty acids content of soybean (Glycine max L. Merrill) seeds. Food Chemistry, v.141, p.3636-3648, 2013. DOI: 10.1016/j.foodchem.2013.06.045.

SOLEYMANIFARD, A.; SIDAT, S.A. Effect of inoculation with bio-fertilizer in different nitrogen levels on yield and yields components of safflower under dry land conditions. AmericanEurasian Journal of Agriculture and Enviromental Sciences, v.11, p.473-477, 2011.

STEFAN, M.; MUNTEANU, N.; STOLERU, V.; MIHASAN, M. Effects of inoculation with plant growth promoting rhizobacteria on photosynthesis, antioxidant status and yield of runner bean. Romanian Biotechnological Letters, v.18, p.8132-8143, 2013.

Received on June 25, 2016 and accepted on February 13, 2017 